\title{
Associations of Contact History, Smoking Status, Nutrition Status, Anti Retrovirus Treatment, and TB HIV Co-infection Among People with HIV/AIDS
}

\author{
Adymulianto Manurung1), Rahayu Lubis²), Kintoko Rochadi3) \\ Masters Program in Public Health, Universitas Sumatera Utara
}

\begin{abstract}
Background: Tuberculosis (TB) and HIV co-infection causes a heavy burden on health care systems and poses particular diagnostic and therapeutic challenges. Studies into predictors of TBHIV co-infection is lacking in Indonesia. This study aimed to examine the associations of contact history, smoking status, nutrition status, ARV treatment, and TB HIV co-infection among people with HIV/AIDS (PLWH).

Subjects and Method: This was a unmatched case-control study conducted in Balige, North Sumatera. A sample of 82 people living with HIV/AIDS was selected for this study, comprising 41 cases with and 41 controls without TB-HIV co-infection. The dependent variable was TB-HIV coinfection. The independent variables were contact history, smoking status, nutrition status, and anti retroviral (ARV) treatment. The data on HIV/AIDS co-infection were taken from the medical record at HKBP Committee HIV/AIDS service. Other variables were measured by questionnaire. Data were analyzed by a multiple logistic regression.

Results: $82.9 \%$ of PLWH had no contact history with TB patients, $56.1 \%$ had poor nutrition status, $78 \%$ were smokers, and $58.5 \%$ had irregular ARV treatment. The risk of TB HIV coinfection increased with poor nutrition status $(\mathrm{OR}=3.48 ; \mathrm{p}=0.014)$, smoking $(\mathrm{OR}=3.39 ; \mathrm{p}=0.021)$, and irregular ARV treatment $(\mathrm{OR}=10.16$; $\mathrm{p}<0.001)$. Test results multiple ARV treatment is the most dominant variable affecting the incidence of $\mathrm{TB}-\mathrm{HIV}$ co-infection $(\mathrm{OR}=8.04 ; 95 \% \mathrm{CI}=2.47$ to 26.18; $\mathrm{p}<0.001)$.
\end{abstract}

Conclusion: The risk of TB HIV co-infection increases with poor nutrition status, smoking status, and irregular ARV treatment.

Keywords: TB, HIV co-infection, nutrition status, smoking, ARV treatment, people living with HIV/AIDS

\section{Correspondence:}

Adymulianto Manurung. Masters Program in Public Health, Universitas Sumatera Utara, Jl. Universitas no.21, Universitas Sumatera Utara, Medan 20115.

Email: adymulianto_manurung@yahoo.com. Mobile: 085296652111.

\footnotetext{
BACKGROUND

HIV (Human Immunoeficiency Virus) is an RNA virus from the retroviridae family and the genus lenitivirus which results in the decreased host body immunity. This virus uses reverse transcriptase to produce DNA copies of RNA viruses in host cells (Gillespie and Kathlen, 2008). According to the World Health Organization (WHO) report in the 2016 Global AIDS Epidemic, the number of global HIV and AIDS cases is
}

36.7 million, the number of new HIV cases is 2.3 million cases, and the mortality caused by AIDS is 1.5 million cases making HIV and AIDS included in the Millennium Development Goal's / MDG's target (WHO, 2016). It is continued with the Sustainable Development Goals (SDGs) with the target of Indonesia in 2030, the incidence of new $\mathrm{HIV}$ infections at the age of 15-49 years is 0.50 / 1000 Indonesian population and the 
Journal of Epidemiology and Public Health (2019), 4(1): 60-64

https://doi.org/10.26911/jepublichealth.2019.04.01.08

incidence of TB 395 / 100,000 Indonesian population WHO Statistics (2017).

HIV and AIDS is a disease that causes a decrease in immunity so that it encourages HIV patients to get other infections. The World Health Organization (WHO) stated that TB co-infection is the most common disease experienced by patients with HIV and AIDS. There are more than 1 million people living with HIV positive TB or $10 \%$ of all global $\mathrm{TB}$ cases in 2016 (WHO, 2016). There are 374,000 or 0.4 million TB deaths among people living with HIV and represents 40\% of all AIDSrelated deaths. People living with TB (+) positively in HIV patients are far more likely to die than people living with TB (-) negative and one in five people (22\%) TB deaths occur among people living with HIV.

Tuberculosis is the most common opportunistic infection in patients with HIV and AIDS. According to WHO report (2017) in the Global Report on Tuberculosis Control, in 2016 the incidence of TB-HIV is estimated to have 1.03 million new cases of TB in HIV patients or 14/100,000 world population and the number of deaths due to TB in HIV positive patients reaches 374,000 or 5/100,000 population. In 2016, there were 1.03 million new cases of TB among people with HIV infection and TB accounted for $36 \%$ of AIDS-related deaths (WHO, 2017). In 2017, WHO stated the Case Fatality Rate (CFR) due to TB in HIV patients was $1.49 \%$, but an increase in the number of TB-HIV co-infection cases was $15 \%$ with a mortality rate of $5 \%$. While new cases of TB coinfection in HIV and AIDS patients in the Southeast Asia region in 2016 reached 16\% (WHO, 2017).

The results of the study by Saputri R.A.S, (2015) concluded that people living with HIV who had a history of contact with TB patients were more at risk of TB-HIV coinfection than those without contact history. In line with the research of Taha et. al. (2013) concluded that people who had contact with TB patients were twice as likely to become ill with TB, but not all who had contact with TB patients made HIV patients infected with TB.

The results of research conducted by Taha et al. (2013) stated that malnutrition is a major risk factor for TB. And conversely TB can cause malnutrition. Kelemu et al. (2013) stated that malnutrition among PLWHA is significant for the occurrence of TB-HIV, because without the adequate nutrition, metabolic stress due to infection will cause weight loss and damage to the body's vital organs so that a person will be easily infected with diseases.

Kelemu et al. (2013) stated that smoking is a factor that influences TB risk in HIV patients, this is proven by the presence of TB co-infected patients whose worse health conditions are caused by smoking. Dwisarwa and Nurlaela's research (2012) states that if the majority of HIV patients in Purwokerto smoke and smoking can interfere with the clarity of the ciliary mucosa which serves as the main defense against infections that enter the lungs. This can facilitate the attachment of bacteria to the respiratory epithelial cells which results in bacterial cholinization and infection.

Braulio et. al. (2008) mentions that PLHIV who are active or routinely taking ARV drugs have managed to restore immune function and reduce morbidity and mortality. The use of ARV therapy in PLHIV reduces the risk of developing active $\mathrm{TB}$ and increasing longer survival. Research on Pili Kemenju et al. (2011) states that many PLWHA do not regularly take ARV drugs and it worsened the condition of PLWHA and can lead to death. 


\section{SUBJECTS AND METHOD}

This was analytic observational with casecontrol design. This study was conducted at the HKBP Balige AIDS Committee Service, in May 2018. Samples of 82 people living with HIV were made up of 41 PLWH with TB and 41 PLWH without TB were selected for this study. The dependent variable was the incidence of TB-HIV co-infection. The independent variables were contact history, smoking status, nutritional status, and ARV treatment. TB status data was taken from the medical record of the AIDS Committee Service of HKBP Balige in 2018. Other variables are measured using a question- naire. The data were analyzed using a multiple logistic regression.

\section{RESULTS}

1. The Results of Bivariate Analysis

Table 1 showed the results of bivariate analysis of the relationship between contact history with TB patients, smoking, nutritional statusand the incidence ofTB-HIV coinfection. Table 1 showed that smoking habit $(\mathrm{OR}=3.39 ; 95 \% \mathrm{CI}=1.30$ to $8.85 ; \mathrm{p}=$ 0.021), poor nutritional status $(\mathrm{OR}=3.49$; 95\% $\mathrm{CI}=1.38$ to $8.80 ; \mathrm{p}=0.014)$, and irregular ARV treatment $(\mathrm{OR}=10.17 ; 95 \%$ $\mathrm{CI}=3.31$ to $31.25 ; \mathrm{p}<0.001)$ increased the risk of TB-HIV co-infection.

Table 1. Bivariate analysis of the relationship between history contacts, smoking, nutritional status, and the incidence of TB HIV co-infection

\begin{tabular}{|c|c|c|c|c|c|c|c|}
\hline \multirow{2}{*}{$\begin{array}{c}\text { Independent } \\
\text { variables }\end{array}$} & \multicolumn{2}{|c|}{ TB-HIV (+) } & \multicolumn{2}{|c|}{ HIV Bukan TB (-) } & \multirow{2}{*}{ OR } & \multirow{2}{*}{$95 \%$ CI } & \multirow{2}{*}{$\mathbf{p}$} \\
\hline & $\mathbf{n}$ & $\%$ & $\mathbf{n}$ & $\%$ & & & \\
\hline \multicolumn{8}{|l|}{ Contact } \\
\hline \multicolumn{8}{|l|}{ Histort } \\
\hline Yes & 16 & $53 \cdot 3 \%$ & 14 & $46.7 \%$ & 1.23 & 0.51 to 3.04 & 0.819 \\
\hline No & 25 & $48.1 \%$ & 27 & $51.9 \%$ & & & \\
\hline \multicolumn{8}{|l|}{ Smoking Habit } \\
\hline Smoking & 32 & $60.4 \%$ & 21 & $39.6 \%$ & $3 \cdot 39$ & 1.30 to 8.85 & 0.021 \\
\hline Not Smoking & 9 & $31 \%$ & 20 & $69 \%$ & & & \\
\hline \multicolumn{8}{|l|}{$\begin{array}{l}\text { Nutritional } \\
\text { Status }\end{array}$} \\
\hline Poor & 23 & $67.6 \%$ & 11 & $32.4 \%$ & 3.49 & 1.38 to 8.80 & 0.014 \\
\hline Good & 18 & $37.5 \%$ & 30 & $62.5 \%$ & & & \\
\hline \multicolumn{8}{|l|}{ ARV } \\
\hline Treatment & & & & & & & \\
\hline Regular & 24 & $82.8 \%$ & 5 & $17.2 \%$ & 10.17 & 3.31 to 31.25 & $<0.001$ \\
\hline Irregular & 17 & $32.1 \%$ & 36 & $67.9 \%$ & & & \\
\hline
\end{tabular}

\section{Multivariate Analysis}

Table 2 showed the distribution of multiple logistic regression analysis results. Table 2 showed that smoking habits, poor nutritional status, and irregular ARV treatment were associated with the incidence of $\mathrm{TB}$ co-infection in PLWH. Smoking habit (OR= $1.74 ; 95 \% \mathrm{CI}=0.58$ to $5.20 ; \mathrm{p} 0.021)$ and irregular ARV treatment $(\mathrm{OR}=8.04 ; 95 \%$
$\mathrm{CI}=2.47$ to $26.18 ; \mathrm{p}=0.001)$ increased the risk of TB co-infection incident in PLWH and it was statistically significant. Poor nutritional status increased the risk of TB co-infection in PLWH and it was statistically nearly significant (marginally significant $)(\mathrm{OR}=2.79 ; 95 \% \mathrm{CI}=0.97$ to $7.97 ; \mathrm{p}=$ 0.056). 
Journal of Epidemiology and Public Health (2019), 4(1): 60-64

https://doi.org/10.26911/jepublichealth.2019.04.01.08

Table 2. The Distribution of Multiple Logistic Regression Analysis Results

\begin{tabular}{|c|c|c|c|c|}
\hline \multirow{2}{*}{ Independent Variables } & \multirow{2}{*}{$\mathbf{O R}$} & \multicolumn{2}{|c|}{$95 \% \mathrm{CI}$} & \multirow[b]{2}{*}{$\mathbf{p}$} \\
\hline & & Lower limit & Upper limit & \\
\hline Irregular ARV Treatment & 8.04 & 2.47 & 26.18 & 0.001 \\
\hline Poor Nutritional Status & 2.79 & 0.97 & 7.97 & 0.056 \\
\hline Smoking Habit & 1.74 & 0.58 & 5.20 & 0.021 \\
\hline
\end{tabular}

\section{DISCUSSIONS}

1. The Effect of Contact History on the Incidence of TB HIV CoInfection among PLWH

The results of the bivariate analysis showed that the contact history had a positive relationship to the incidence of TB-HIV coinfection, but it was not statistically significant. This study was in line with Muguleta et.al. (2015) in Ethiopia which stated that the majority of study subjects had no contact history with TB patients (67\%). The results of the analysis also stated that there was an effect of contact history on the incidence of TB-HIV co-infection in Ethiopia, but it was not statistically significant (p>0.05).

\section{The Effect of Smoking Habit on the Incidence of TB HIV Co-Infection among PLWH}

The results of multivariate analysis showed that there was a relationship between smoking habits and the incidence of TBHIV co-infection at the HKBP Balige AIDS Committee service. PLWHA who smoke were 1.74 times more likely to suffer from TB co-infection than those who did not smoke.

A study by Kelemu et al. (2013) stated thatsmoking was a factor that affected the risk of TB in HIV patients by $25 \%$. Smoking increased the risk of TB in people with HIV/AIDS by 3.34 times $(\mathrm{OR}=3.34$; $\mathrm{p}<0.001)$. His findings indicated the condition of PLWHA patients with co-infected TB have poor conditions of lung health.

\section{The Effect of Nutritional Status on the Incidence of TB HIV Co- Infection among PLWH}

The results of multivariate analysis showed that there was a relationship between nutritional status and the incidence of TBHIV co-infection in PLWHA. Nutritional status did not increase the risk of TB-HIV co-infection in PLWHA by 2.79 times and marginally significant. Taha et al. (2013) stated that nutritional status (MT $\leq 17.5$ ) affected TB-HIV co-infection in PLWHA $(\mathrm{OR}=4.1 ; \mathrm{p}<0.001)$.

\section{The Effect of ARV Treatment on the Incidence of TB HIV Co- Infection among PLWH}

The results showed that there was a relationship between ARV treatment and the incidence of TB-HIV co-infection in PLWHA in the HKBP Balige AIDS Committee service. Irregular ARV treatment was 8.04 times more likely to get TB co-infection in PLWHA. Kemenlu et al. (2013) showed that there was an effect of ARV treatment on the incidence of TB-HIV co-infection $(\mathrm{OR}=3.7 ; \mathrm{p}<0.005)$ and it was statistically significant. The result of this study was in line with Taha et al. (2013) who stated that ARV treatment was significantly associated with the incidence of TB-HIV co-infection $(\mathrm{OR}=3.1 ; \mathrm{p}<0.001)$.

\section{REFERENCES}

Bráulio M, André JM, Roberto JN, Thalles BG, Cristiane CF (2008). Factor Related to HIV/Tubercuosis Coinfection in a Brazilian Reference Hospital. 4: 281-286. 
Dwisarwa S, Nurlaela (2011). Merokok dan Tuberkuosis Paru (Studi Kasus do RS Margono Soekardjo Purwokerto).

Gelliespie, BamfordK (2007). Mikrobiolgi Medis dan Infeksi, Erlangga Medical Series, Jakarta.

Global report (2017).hiv/aids epidemic 2016, diakses oktober 2017, http://www.unaids.org/sites/default/ files/media_asset/global-AIDSupdate-2016

Global report (2017).koinfeksi tb/hiv epidemic, diakses oktober $2017 \mathrm{http}: / /-$ www.unaids.org/sites/default/files/m edia_asset/2017_data-book

Global report (2017). Progress report on HIV in the WHO South-East Asia Region 2016 http://apps.searo.who.int/PDS_DOCS/B5282

Kelemu TK, Alemayehu WY, Belaineh GB, Muuken MA (2013). Determinant factors Associated with Occurrence of Tuberculosis among Adult People Living with HIV after Antiretroviral treatment Initiation. Addis Ababa, Ethiopia. 8(5).

Kementerian Kesehatan Republik Indonesia(http://www.spiritia.or.id/Dok/juknistbhiv2013.pdf diakses pada 30 Oktober 2017).

Taha M, Amarew D, Tessema F, Assegid S, Duchateau L, Colebunders R (2013). Risk Factor of Actife Tuberculosis in People Living With HIV/AIDS in Southwest Ethiophia. 2: 131-139.

Mulugeta B, Bjune G,Abebe F (2015). Prevalence of tuberculosis, HIV, and TB-HIV co-infection among pulmonary tuberculosis suspects in a predominantly pastoralist area, northeast Ethiopia.

Pili K, Aboud S (2011). Tuberculosis-HIV Co-Infection among Patients Admitted at Muhimbili National Hospital in Dar es salaam, Tanzania.

Saputri RAS (20015). Faktor-faktor Koinfeksi TB Paru Pasien HIV/AIDS di Balai Kesehatan Paru Masyarakat Semarang. 